\title{
Tafsir Indonesia di Rezim Otoritarianisme
}

\author{
Ihsan Nursidik \\ UIN Sunan Gunung Djati Bandung \\ sanssidik22@gmail.com
}

\section{Suggested Citation:}

Nursidik, Ihsan. (2021). Tafsir Indonesia di Rezim Otoritarianisme. Jurnal Iman dan Spiritualitas, Volume 1, Nomor 2: pp 198203. http://dx.doi.org/10.15575/jis.v1i2.12072

\section{Article's History:}

Received 2021-03-21; Revised 2021-04-17; Accepted 2021-05-05.

2021. journal.uinsgd.ac.id @. All rights reserved.

\begin{abstract}
Abstrak:
Otoritarianisme ialah pemerintah yang dikuasai oleh kekuatan mutlak pada satu orang. Pemerintahan seperti ini pernah terjadi di Indonesia, lebih tepatnya yang dikenal sebagai Orde Lama dan Orde Baru. Pada rezim inilah pengaruh-pengaruh untuk mempertahankan kekuasaan begitu masif diinfiltrasikan sebagai wacana. Diantara infiltrasi tersebut aktivitas penafsiran AlQur'an turut terlibat dalam usaha untuk menguasai panggung politik kala itu. Penafsiran Al-Qur'an menjadi salah satu domain untuk memproduksi wacana rezim sekaligus gerakan-gerakan kritik terhadapnya. Penelitian ini merupakan studi pustaka dengan menggunakan metode penelitian kualitatif deskriptif. Dalam penelitian ini dapat diketahui bahwa otoritarianisme telah menjadi semacam medan makna yang mempengaruhi ruang publik kala itu. Sehingga para aktor yang terlibat di dalamnya, memproduksi pemahaman Al-Qur'an berdasarkan pengaruh dari efek otoritarianisme yang menyertainya pada saat itu
\end{abstract}

Kata Kunci: Orde Lama, Orde Baru, Tafsir Al-Qur'an, Medan Makna

\begin{abstract}
:
Authoritarianism is a government-controlled by absolute power in one person. This kind of government has occurred in Indonesia to precisely what is known as the Old Order and the New Order. It is in this regime that the influences to maintain power are massively infiltrated as discourse. Among these infiltrations, the activity of interpreting the Koran was also involved in the effort to dominate the political stage at that time. The interpretation of the Koran is one of the domains for producing regime discourse and movements to criticize it. This research is a literature study using descriptive qualitative research methods. In this research, authoritarianism has become a kind of field of meaning that affects the public sphere at that time. So that the actors involved in it, produce an understanding of the Koran based on the influence of the effects of authoritarianism that accompanied it at that time.
\end{abstract}

\section{Keywords: Old Order, New Order, Interpretation of Quran, Discourse}

\section{PENDAHULUAN}

Perjalanan Bangsa Indonesia dimulai pasca kemerdekaan 1945 yang mana pemerintahan menetapkan Presiden Soekarno dan Hatta sebagai Presiden dan Wakil Presiden. Namun romantisme antara Soekarno dan Hatta ini tidak berjalan lama, hingga akhirnya pucuk pemerintahan dipegang oleh Presiden Tunggal, yaitu Ir. Soekarno (Rahman 2010). Pasca perseturuan konstituante di pemerintahan parlementer pada tahun 1950 hingga terbitnya Dekrit President 5 Juli 1959, Presiden Soekarno mulai mengukuhkan posisinya di pucuk pemerintahan yang ditandai dengan penetapan kembali UUD 1945 dan pembubaran Konstituante. Rezim Presiden Soekarno inilah yang disebut sebagai Orde Lama, yang dikenal pula sebagai Demokrasi Liberal atau Demokrasi Terpimpin (Siregar 2011). Sejak dikeluarkan Dekrit Presiden 5 Juli 1959, sebagaimana Yahya Muhaimin yang dikutip Mahfud MD, 'Dekrit Presiden 5 Juli 1959 telah menjadi gong penutup bagi kehidupan demokrasi parlementer.' Sejak dikeluarkan dekrit itu, dimulailah langgam otoritarian dalam kehidupan politik di Indonesia dibawah bendera Demokrasi Terpimpin (Kamsi 2013). Selama kurun waktu 1959-1965 Presiden dengan sistem Demokrasi Terpimpin menjelma menjadi pemimpin otoriter dengan kedok Demokrasi Terpimpin.

Gerakan 30 September yang diprakarsai oleh PKI, yaitu peristiwa pembunuhan 6 perwira tinggi dan 1 perwira menengah. Peristiwa ini kemudian dinamai dengan G30S PKI, dan dari peristiwa ini pulalah timbul berbagai sinyal tuntutan dari massa. Massa yang tergabung pada aliansi masyarakat utamanya yang diwakili oleh pelajar seperti, Pemuda dan Pelajar Indonesia 
(KAPPI) dan Kesatuan Aksi Mahasiswa Indonesia (KAMI). Kesatuan Aksi yang dibentuk pada tanggal 25 Oktober 1965 mengetengahkan Tri Tuntutan Rakyat (TRITURA) dan Tuntutan Hatinurani Rakyat (TUNHANURA) (Kamsi 2013).

Hingga sampai pada terbitnya Surat Perintah 11 Maret (Supersemar) 1996 yang ditujukan kepada Soeharto. Sebagaimana dituliskan oleh Mahfud MD (2009), sebagai berikut:

Pertama mengambil segala tindakan yang dianggap perlu, untuk terjaminnya keamanan ketenangan serta kestabilan jalannya pemerintahhan dan jalannya revolusi, serta menjamin keselamatan pribadi dan kewibawaan Pemimpin/ Presiden/ Panglima Tertinggi/ Pemimpin Besar Revolusi/ Mandataris MPRS demi untuk keutuhan bangsa dan Negara Republik Indonesia, Kedua mengadakan koordinasi pelaksanaan pemerintahan dengan panglima-panglima angkatanangkatan lain dengan sebaiknya. Ketiga, supaya melaporkan segala sesuatu yang bersangkut-paut dalam tugas dan tanggung jawabnya seperti tersebut diatas (MD 2009).

Dengan diterimanya memorandum ini, maka kedudukan Soeharto sebagai tokoh utama dalam pemerintahan semakin kuat karena dalam memorandum itu disebutkan Supersemar sebagai dasar hukum bagi lahirnya Orde Baru di bawah pimpinan Soeharto. Rezim inilah yang berkuasa sekitar tiga dasa warsa di Indonesia dengan sistem politik otoriter yang dinamainya Demokrasi Pancasila.

Kedua Rezim ini tentunya telah melahirkan suatu tatanan narasi yang yang dimodali oleh totalitarianisme. Sebagaimana yang diterangkan oleh Foucault yang dikutip oleh Agus Sudibyo (Sudibyo 1998), 'Pengetahuan dan Kekuasaan mempunyai hubungan timbal-balik. Penyelenggaraan kekuasaan yang terus-menerus akan menciptakan entitas pengetahuan, sebaliknya, penyelenggaraan pengetahuan akan selalu menimbulkan kekuasaan'. Aditjondro menegaskan bahwa konsekuensi suatu kekuasaan juga perlu diselidiki sebagai kajian atas pengaruh-pengaruh pengetahuan (Aditjondro et al. 2000). Pengaruh itu diciptakan dalam representasi wacana (buku, media cetak, film, pidato dan lain-lain) dan merupakan hasil dari praktek-praktek diskursif (implementasi dan operasionalisasi dimensi wacana untuk menghasilkan image, citra dan efek-efek tertentu dalam presentasi tekstual maupun lisan).

Menurut Ekarini Saraswati (1998), Rezim Orla memiliki gaya bahasa yang bombastis yang diungkapkan dalam sloganslogan dan akronim khas Soekarnois. Kata "Revolusi" dengan tendensi bahwa rezim sedang melakukan revolusi besar untuk membangun Dunia Baru dan menjungkirbalikkan dunia yang sekarang. Tawaran perlawanan kepada segala bentuk kolonialisme dan imperialisme (Wibisono 2021). Adapun Orde Baru menjual jargon-jargon pembangunan, seperti 'akselerasi', 'tinggal landas', 'pertumbuhan teknologi, 'moderasi', 'efisiensi' dan sebagainnya. Belum lagi dengan ujaran-ujaran yang diungkapan eufemisme yang dibudayakan dalam politik Orde Baru.

Hal tersebut pun berlaku pada wacana Tafsir Al-Quran. Penafsiran Al-Quran sebagai salah satu aktifitas diskusus telah mewujudkan representasi dari wacana dalam memperoleh legitimasi atau kritik terhadap kekuasaan yang berlaku (Zulaiha 2017). Rezim Orde Lama (Orla) dan Orde Baru (Orba) memiliki perbedaan cara dalam upaya indoktrinasi nilai-nilai ideologi dalam mewujudkan pemerintahannya. Sehingga dapat dilihat pula varian penafsir yang berada diantara lingkaran pemerintah yang memiliki kecenderungan untuk melegitimasi produk politik rezim dan di luar lingkaran pemerintah yang bersifat ofensif terhadap segala bentuk otoritarianisme rezim.

\section{METODE}

Tafsir sebagai salah satu wilayah penelitian teks, sangat erat kaitannya dengan keilmuan dalam bidang humaniora, sebagaimana disebutkan oleh Rukin (2019), bahwa penelitian humaniora sangatlah khas dijadikan sebagai objek kajian dari penelitian-penelitian kualitatif.. Sifatnya yang deskriptif-analisis menjadi karakteristik dari penelitian ini (Anggito and Setiawan 2018). Lebih lanjut, penelitian kualitatif sangat berkonsentrasi pada "makna" dari sesuatu hal. Sehingga memperjelas posisi daripada kajian-kajian Tafsir Al-Qur'an dalam wilayah penelitian ini.

Penelitian ini berbasis pada kajian literatur (library research) dengan menggali sumber-sumber literatur (Sugiyono 2015). Pada penelitian ini,, peneliti bermaksud untuk mendeskripsikan situasi lahirnya penafsiran-penafsiran diera otoritarianisme. Melalui pendekatan social-historis, peneliti bermaksud mencari relasi-relasi historis dan sosial secara global yang meliputi konteks penafsiran pada era tersebut

\section{HASIL DAN PEMBAHASAN}

\section{Keindonesiaan dalam Tafsir Al-Quran}

Tafsir yang berkembang di Indonesia dapat dilacak dari manuskrip-manuskrip klasik yang bertebaran di seantero bumi nusantara. Seorang Indonesianis A.H John dalam "The Qur'an in the Malay World: Reflection on 'Abd al-Ra'uf Singkel (16151693)" mengkaji tentang karakteristik tafsir, keterpengaruhan serta proses adopsi yang terjadi. Indonesianis lain, seperti Peter G. Riddell dan Howard. Federspiel, melakukan kajian mengacu kepada pengaruh dan dinamika Islam di timur Tengah dan Tafsir Al-Quran Indonesia dalam bentuk respon dan transmisinya. Lebih jauh Federspiel juga mengkaji karakteristik terjemahan dan tafsir Al-Quran di Asia Tenggara dan kepopulerannya (Gusmian 2005).

Kajian yang dilakukan oleh para indonesianis tersebut telah memberikan gambaran mengenai sosok penafsir di Indonesia. Islah Gusmian pun turut memberikan paparan mengenai kategorisasi penafsir di nusantara. Secara umum hal tersebut dapat terlihat dari dua prespektif besar, yaitu prepektif penafsir dalam basis sosial dan budayanya serta prespektif penafsir dalam identitas sosial dan basis keilmuan. Masing-masing dari prepektif tersebut, Islah Gusmian membaginya kembali pada lima kategori (Gusmian 2015). 
Merujuk pada penafsir dalam basis budaya, Islah Gusmian membaginya menjadi lima. Pertama, basis sosial politik kekuasaan contohnya Tafsir Al-Misbah karya Qurasih Shihab ditulis ketika ia menjabat sebagai Duta Besar Indonesia di Mesir (Shihab 2002). Contoh lainnya seperti Pemerintah Republik Indonesia melalui Kementrian Agama yang menyusun Tafsir Tematik pada tahun 2008 dikeluarkan oleh Lajnah Pentashih Mushaf Al-Quran Kementrian Agama RI. Kedua, basis pendidikan pesantren misalnya, Al-Ibriz li Ma'rifati Tafsir al-Quran al-Aziz (1960) karya K.H. Bisri Mustofa (1915-1977) (Ma'arif and Nabila 2020), Iklil fi Ma'ani at-tanzil (1980) dan Taj al-Muslimin karya K.H. Misbah ibn Zainul Mustofa-Pemimpin Pesantren Al-Balagh di Bangilan, Tuban-(1916-1994) dan Jami' al-Bayan karya K.H. Muhammad ibn Sulaiman. Raudat al-Irfan fi 'a'rifah al-Quran dan Tamsyiyatul Muslimin fi Tafsir Kalam Rabb al-Alamin karya K.H. Ahmad Sanoesi-Seoang pengasuh Pesantren Kedung Puyuh, Sukabumi pada 1932 M. Pendiri Ittihadijatoel Islamijjah (All). Serta ikut berperan dalam pembentukan Peta (pembela Tanah Air) di Bogor pada 1943 M. Kemudian terlibat pula dalam Badan Usaha Persiapan Kemerdekaan Indonesia (BPUPKI) dan Panitia Persiapan Kemerdekaan Indonesia (PPKI). Ketiga, basis pendidikan formal I seperti, Anre Gurutta H.M. As'ad (w.1952) yanng menulis Tafsir Bahasa Boegisja Soerah Amma. Anre Gurutta Daud Ismail (1908-2006) menulis tafsir bahasa dan aksara bugis yang berjudul Tafsir Munir, Tarjamah wa Tafsir al-Juz al-Awwal wa al-Tsani waal-Tsalits Tokoh lain dari Sulawesi seperti Anre Gurutta H.M. Yunus Martan (w.1961) yang menulis Tafsir Al-Quran al-Karim bi al-Lughah al-Bugisiyyah, Tafsere Akorang Bettuwang Bicara Ogi. Selain ketika penafsir tesebut dapat ditemukan pula penafsir lainnya seperti Mahmud Yunus (1899-1982 M), Omar Bakry (1916) yang menulis Tafsir al-Madrasi dan Tafsir Rahmat. Kemudian basis pendidikan formal II yaitu tafsir yang lahir di rahim kampus misal, T.M Hasbi Ash-Shiddieqy dosen IAIN Sunan Kalijaga Yogyakarta, menulis Tafsir Al-Nur (1952) dan Tafsir Al-Bayan (1966); Bakri Syahid (1918-1994) menulis Al-Huda, Tafsir Al-Quran Boso Jawi ketika menjabat sebagai rektor IAIN Sunan Kalijaga Yogyakarta. Keempat, basis organisasi sosial seperti, Muhammadiyah yang menerbitkan Kuran Jawen dan Persis yang menerbitkan Tafsir Al-Furqan. Kemudian yang terakhir dari kalangan pendidik yang berada diluar basis sosial yang spesifik, terdapat Tafsir Al-Azhar karya Hamka, Ayat Suci Dalam Renungan karya Mohammad Emon Hasim. Mucnul Quraish Shihab, Jalaluddin Rahmat, M. Dawam Raharjo dan Syu'bab Asa (Gusmian 2015).

Adapun bila ditinjau dari segi identitas sosial dan basis keilmuan penafsir maka para penulis tafsir tersebut, dapat dikategorikan pula ke dalam lima kelompok. Pertama, identitas sosial ulama, seperti Kiai Saleh Darat penulis Faid al-Rahman; Mhd. Romli (1889-1981), penulis al-Kitab al-Mubin: Tafsir Al-Quran Basa Sunda; Abdullah Thufail Saputra (1927-1992), penulis Tafsir Al-Quran Gelombang Tujuh; Oemar Bakry penulis tafsir Rahmat; Misbah Zainul Mustafa (1916-1994), penulis tafsir alIklil fi Ma'ani at-Tanzil; Didin Haifidhuddin penulis Tafsir Al-Hijri dan M. Quraish Shihab penulis Tafsir Al-Misbah. Kedua, identitas sosial cendikiawan, seperti Jalaluddin Rakhmat penulis Tafsir bil Ma'tsur (pakar ilmu komunikasi) dan M. Dawam Rahardjo penulis Ensiklopedi Al-Quran (pakar ilmu ekonomi). Ketiga, identitas sastrawan-budayawan misalnya, Syu'bah Asa (1941-2011) penulis Dalam Cahaya Al-Quran dan Moh. E. Hasim-Dikenal pula sebagai seorang guru dan penulis yang menguasai bahasa Arab, Inggris, Jepang - (1916-2009), penulis Ayat Suci dalam Renungan. Keempat, identitas sosial birokrat seperti, Abdoel Moerad Oesman (1991)_Pernah aktif di Lasykar Hizbullah, TNI Angkatan Darat (1945-1985), ikut dalam operasi penumpasan Gerakan 30 September 1965, dan Perwira Rohani Islam di Istana Negara—penulis Al-Hikmah; Bakry Syahid (1979)—Seorang Komandan Kompi, Wartawan Perang No. 6-MTB, Kepala Staf Batalion STM-Yogyakarta, Kepala Pendidikan Pusat Rawatan Ruhani Islam Angkatan Darat, Wakil Kepala Pusroh Islam Angkatan Darat, dan Asisten Sekertaris Negara Republik Indonesia-penulis Al-Huda; dan M. Quraish Shihab, penulis Wawasan Al-Quran. Kelima, Identitas sosial politikus misalnya, Oemar Bakry (1984)_Pernah aktif di Partai Politik Persatuan Muslim Indonesia (PERMI) dan menjadi pimpinan Masyumi di Sumatra Tengah, Misbah Zainul Mustafa-Pernah aktif di Partai Masyumi, Partai Persatuan Indonesia (PPI), dan kemudian dipaksa aktif di Gokar oleh Rezim Orde Baru, dan Didin Hafidhuddin-Aktif di bidang pendidikan dan dakwah, ia pernah berkiprah di Partai Keadilan (PK_cikal bakal Partai Keadilah Sejahtera (PKS) (Husni 2019).

\section{Khulashoh Tafsir Produk Rezmi Orde}

Dalam pandangan semiotika sosial, teks tidak akan terlepas dari situasinya. Hal ini berlaku pula dalam konteks penafsiran al-Quran. Sebagaimana yang diterangkan oleh Haliday dan Ruqayya Hasan, yang dikutip oleh Syamsul Wathani setidaknya terdapat tuda konteks situasi yang berlaku: (1) Medan wacana yakni hal yang terjadi dan sedang berlangsung; (2) Pelibat peran, (3) Sarana wacana, yakni bagian yang sedang diperankan oleh bahasa dalam situasi (Wathani 2016) .

Pada medan wacana, baik Orde Lama maupun Orde baru sama-sama menampilkan ketegangan pada kekuasaan otoriter. Pemegang mutlak kekuasaan berhak menjadi penentu dari setiap kebijakan-kebijakan pemerintahan. Pelibat dalam hal ini ialah para kalangan intelektual yang telah disebutkan sebelumnya, terbagi kepada para kalangan yang memiliki basis sosial politik atau basis sosial pendidikan. Serta dalam sarana wacananya, para aktor ini bergerak dalam memproduksi bahasa melalui tafsir Al-Quran.

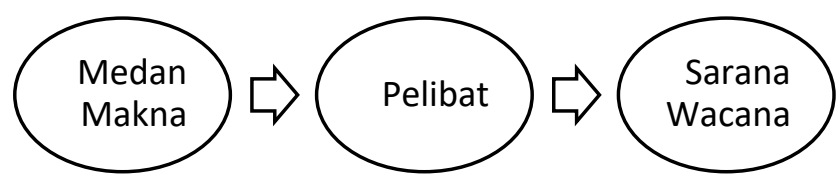


Konstelasi gagasan ini berkutat pada pihak penentang serta pendukung rezim kala itu. Situasi ini memberi gambaran pada penafsiran Al-Quran yang mendominasi keberadaan tafsir di Indonesia. Dapat dilihat dari penfasiran Bakri Syahid misalnya sebagai orang yang berada dilingkaran pemerintahan menjelaskan makna ulu al-amr dalam Q.S. an-Nisa [4]: 83 dan Q.S. Yunus [10]:7 sebagai berikut:

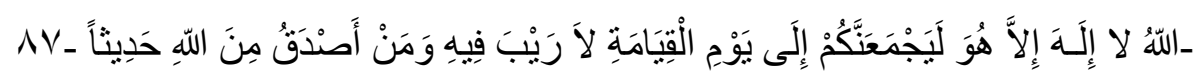

"Dan apabila sampai kepada mereka suatu berita tentang keamanan ataupun ketakutan, mereka (langsung) menyiarkannya. (Padahal) apabila mereka menyerahkannya kepada Rasul dan Ulul Amri di antara mereka, tentulah orangorang yang ingin mengetahui kebenarannya (akan dapat) mengetahuinya (secara resmi) dari mereka (Rasul dan Ulul Amri) ${ }^{* *}$. Sekiranya bukan karena karunia dan rahmat Allah kepadamu, tentulah kamu mengikuti setan, kecuali sebagian kecil saja (di antara kamu) (Q.S. an-Nisa: 83).

Perihal Ulu al-Amri menurut Bakri Syahid (1979), "untuk kontek sekarang, Ulul al-Amri itu perintah yang menjalankan sistem demokrasi, seperti pemerintah Indonesia yang menerapkan sistem Demokrasi Pancasila."

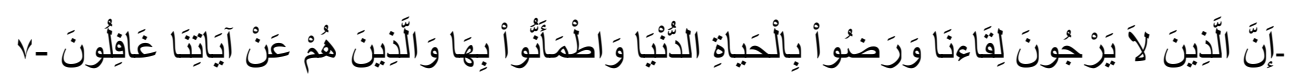

"Sesungguhnya orang-orang yang tidak mengharapkan (tidak percaya akan) pertemuan dengan Kami, dan merasa puas dengan kehidupan dunia serta merasa tenteram dengan (kehidupan) itu, dan orang-orang yang melalaikan ayat-ayat Kami." (Q.S. Yunus: 10)

Pada ayat ini dia menilai, "Paham sekularisasi itu berlawanan denga ajaran Agama Islam dan juga tidak bisa diterapkan di negeri Pancasila Indonesia, Sebab, falsafah dan ideologi Pancasila itu menetapkan di Undang-undang Dasar (UUD) 1945, Bab IX Pasal 29, bahwa 'Negara berdasar atas Ketuhanan Yang Maha Esa' (Syahid 1979).

Bakri Syahid menafsirkan pula Q.S. Yunus [10]: 19 yang meletakkan wawasan kenusantaraan dan kebangsaan sebagai satu dasar penulisan tafsirnya, yaitu dengan memasukan amanat Pancasila dan Undang-undang Dasar (UUD) 1945 (Gusmian 2005).

Akan tetapi hal ini justru ditanggapi lain oleh Moh. E. Hasim yang mengkritik kebijakan ekonomi rezim Orde Baru sebagai sistem lisensi yang hanya memberikan keuntungan kepada pihak tertentu. Lebih jauh diterangkan oleh Jajang A. Rohmana bahwa Hasim ini merespon beberapa kebijakan Orba diantaranya PORKAS, KSOB atau SDSB; pelarangan hijab ketika menafsirakan Q.S. Al-Baqarah [2]: 132; kritik atas dampak SDSB seperti adanya peristiwa pembunuhan pada 11 Oktober 1993, kyai penghulu yang bernasib baik dibanding guru mengaji atau merebot yang miskin (Hashim 2007).

Dalam Q.S. An-Nisa [4]: 58-59 dapat dilihat beberapa singgungan mengenai pemerintah, khususnya Hamka pada Rezim Orde Lama dan Syu'bah Asa pada Rezim Orde Baru, sebagai berikut:

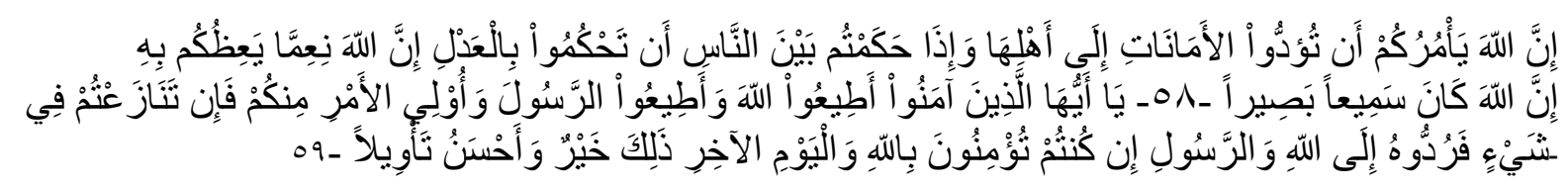

"Sungguh, Allah Menyuruhmu menyampaikan amanat kepada yang berhak menerimanya, dan apabila kamu menetapkan hukum di antara manusia hendaknya kamu menetapkannya dengan adil. Sungguh, Allah sebaik-baik yang Memberi pengajaran kepadamu. Sungguh, Allah Maha Mendengar, Maha Melihat. Wahai orang-orang yang beriman! Taatilah Allah dan taatilah Rasul (Muhammad), dan Ulul Amri (pemegang kekuasaan)** di antara kamu. Kemudian, jika kamu berbeda pendapat tentang sesuatu, maka kembalikanlah kepada Allah (al-Quran) dan Rasul (Sunnahnya), jika kamu beriman kepada Allah dan hari kemudian. Yang demikian itu, lebih utama (bagimu) dan lebih baik akibatnya" (Q.S. An-Nisa 5859).

Hamka memberi judul tersendiri dalam pefasiran Q.S An-Nisa ayat [4]: 59 ini dengan "Ketaatan kepada Penguasa". Hal ini menjadi penekanan terhadap perkara penguasa. Hamka menerangkan:

"Ulil amri, orang-orang yang menguasai pekerjaan, tegasnya orang-orang berkuasa diantara kamu, atas daripada kamu. Minkum menurut Hamka memiliki dua arti. Pertama diantara kamu, kedua daripada kamu. Maksudnya ialah mereka yang berkuasa itu adalah dariapda kamu juga, naik atau terpilih atau kamu akui kekuasaannya, sebagai satu kenyataan".

Hamka juga mengkaitkan keharusan ulil amri dalam menjaga stabilitas pemerintahan dengan melaksanakan Syura (musyawarah) dalam mengambil setiap kebijakan. Hamka pun mengutip Q.S. Ali Imran [3]: 159 dan Q.S. Asy-Syura [42]: 38 sebagai penekanan terhadap pentingnya syura dalam pengambilan suatu keputusan (Wahid 2017). Penafsiran ini tentu menjadi media untuk Hamka mengkritik Rezim Soekarno yang otoriter hingga menjebloskannya ke penjara.

Syu'bah Asa sebagaimana disimpulkan oleh Munadzir dalam tulisannya, menyimpulkan Syu'bah memulai penafsirannya dengan kata hakama pada Q.S. An-Nisa [4]: 58 sebagai pemerintah, dan menjadikan ahlul halli wal 'aqdi sebagai orang yang berkompeten dalam menyelesaikan suatu persoalan. Lalu ulil amri, ditafsirkannya sebagai pemegang kuasa itu sendiri. Lanjutnya, Syu'bah memberikan penekanan pada Q.S. An-Nisa [4]: 58 sebagai perintah bagi pemimpin agar berlaku adil dan 
bijaksana. Kemudian pada Q.S. An-Nisa [4]: 59 kewajiban kepada warga negaranya untuk menaati pemimpinnya (Munadzir 2017). Syu'bah juga menerangkan QS. Al-An'am [6]: 65 yang memuat dampak-dampak buruk dari korupsi, kolusi dan nepotisme (Asa 2000).

\section{Tipologi Penafsiran dan Motif Kepentingan dalam Tafsir Indonesia}

Islah Gusmian (Gusmian 2005), dalam disertasinya yang berjudul "Dialektika Tafsir al-Quran dan Praktik Politik Rezim Orde Baru" terdapat beberapa asumsi dalam penafsiran kala itu. Pertama, gerakan publikasi tasir jelas bukan sekedar perajut kesinambungan sejarah penafsiran Al-Quran. Kedua, dalam konteks politik, karya tafsir tersebut menjadi penanda mengenai eksistensi tafsir al-Quran denyut rezim orba. Ketiga, kepentingan otoriter ini, tafsir al-Quran yang ada dikarang bahkan menyentuh tema-tema sensitif ketika itu, seperti: kemiskinan, ketidakadilan, musyawarah, pancasila dan lain-lain. Hemat penulis asumsi-asumsi ini pun berlaku bagi kondisi Rezim Orde Lama. Sebab kelahiran tafsir al-Azhar yang masyhur ditengahtengah masyarakat saat ini pun, dimotivasi atas kebutuhan menanggapi otoriterianisme, apalagi mengingat karya ini ditulis akibat konsekuensi politik perseturuan Hamka dengan Soekarno. Meskipun Rezim Orde Lama hanya melewati masa yang relatif dibandingkan Rezim Orde Baru, motivasi penulisan tafsir telah berkembang dan menjadi bagian dari kebutuhan legitimasi wacana sebagai kekuatan politik.

Sebagaimana yang telah disebutkan di awal orientasi penfasiran ini akan bertumpu pada wacana terhadap legitimasi rezim dan disisi lain sebagai wacana yang meng-counter rezim tersebut. Menurut Islah terdapat dua macro context dari penafsiran pada era rezim. Pertama, kebijakan yang bertentangan dengan kepentingan dan misi umat Islam. Kedua, Kebijakan rezim orde baru-dan orde lama-yang pro-kontra dikalangan umat Islam (Gusmian 2015). Hal inilah yang memicu pemerintah/rezim pada saat itu memproduksi wacana sebagai usaha legitimasi atas kebijakan bahkan lebih mengarah kepada pengukuhan kekuasaan. Sedangkan di pihak lain yang menentang kebijakan pemerintah diprakarsai sekaliber intelektual yang berlatarkan ulama atau pendidik.

Lewat pergumulan historis tersebut, Islah lebih lanjut membagi konstelasi wacana penafsiran ini pada tiga prespektif. Pertama Prespektif Bafsir Bungkam, dengan corak teosentris tekstual, dan mengambil audiensi pada elite kekuasaan dan politik otosentor. Kedua Prespektif Tafsir Gincu, dengan analisis pada penekanan peran tafsir sebagai peneguhan kebijakan dan kekuasaan rezim. Ketiga Prespektif Tafsir Kritis, dengan analisis tafsir sebagai ruang kritik atas kekuasaan rezim. Prepektif ini diorong oleh analisis sosial-politik dan kesadaran sejarah penafsir (Gusmian 2015).

Dari tiga prepektif ini otoriterianisme disokong oleh produk tafsir bungkam dan gincu yang memperdaya kesadaran masyarakat sekaligus oleh penafsiran yang betul-betul di orientasikan untuk mengakomodasi segala kebijakan pemerintah kala itu. Adapun arus kritis berada sebagai oposisi yang mengkonfrontir segala kebijakan pemerintah yang bertentangan dengan kepentingan umat Islam Indonesia pada saat itu.

Perebutan wacana ini memprakarsai perdebatan antara produk tafsir pada lingkaran rezim dan tafsir pada luar lingkaran rezim atau gerakan konfrontasi. Mengutip Foucault, menurutnya wacana (knowladge) dapat diidentifikasi dengan mengetahui discursive practice-nya (Allen 2010). Discursive practice ini penulis artikan sebagai satuan sistem dalam setiap produk gagasan. Artinya setiap wacana akan menghasilkan sistem mengenai macam-macam produk gagasan yang benarditerima-dan laten-ditolak.

Penafsiran Al-Quran pada saat itu telah menjadi wahana untuk mendominasi wacana di elit politik Indonesia. Pada pihak penguasa rezim, tafsir menjadi alat untuk memperkukuh jabatannya sedangkan pada pihak konfrontir, tafsir menjadi alat untuk meruntuhkan rezim yang berkuasa. Maka dapat dipetakan berdasarkan daripada paparan sebelumnya, terkhusus pada dua karya Islah Gusmian yang telah begitu gambang mempetakan kondisi tersebut, penulis mencoba mengkonsepkan peranan tafsir pada zaman otoritarianisme tersebut. Bila digambarkan secara konseptual maka dapat dijelaskan sebagai berikut:

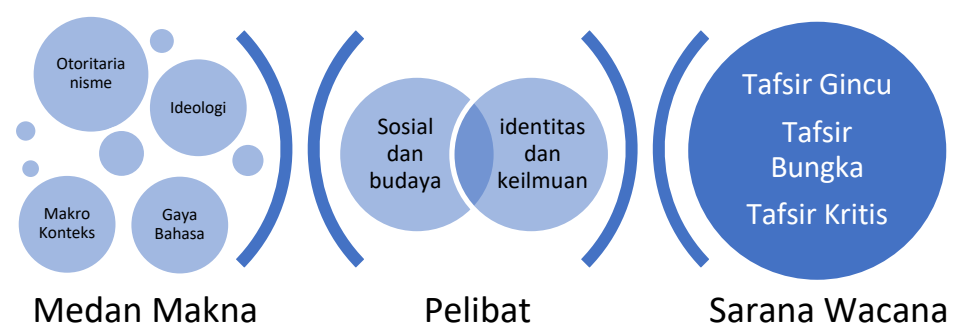

\section{KESIMPULAN}

Penafsiran Al-Quran pada Rezim Orde Lama dan Orde Baru merupakan bagian dari kekayaan penafsiran Nusantara. Penafsiran Al-Quran pada era tersebut melibatkan aktor-aktor intelektual yang berkecimpung dalam kehidupan sosial-politik dan berdasarkan pada latar belakang intelektuan dan identitas social yang beragam. Penafsiran Al-Qur'an yang sarat akan dimensi makna telah menghadirkan satu pergulatan wacana yang khas. Tafsiran Al-Qur'an yang mensyaratkan dominasi atas wacana diantara dua belah pihak. Pertama, pihak pemerintah (rezim) yang memproduksi tafsir yang melegitimasi 
pemerintahannya (tafsir gincu atau tafsir bungkam). Kedua, pihak konfrontir yang memproduksi tafsir untuk mengkritik segala kebijakan pemerintah yang bertentangan dengan kepentingan Islam saat itu (tafsir kritis).

\section{DAFTAR PUSTAKA}

Aditjondro, George, Ronald Francisco, Linda Camp Keith, John C. King, David Kowalewski, Drew Noble Lanier, Chris Lee, Kathleen A. Mahoney-Norris, Sandra Maline, and Susan McMillan. 2000. Paths to State Repression: Human Rights Violations and Contentious Politics. Rowman \& Littlefield Publishers.

Allen, Barry. 2010. "Foucault's Theory of Knowledge." Foucault and Philosophy 143.

Anggito, Albi, and Johan Setiawan. 2018. Metodologi Penelitian Kualitatif. CV Jejak (Jejak Publisher).

Asa, Syu'bah. 2000. "Dalam Cahaya Al-Qur'an: Tafsir Ayat-Ayat Sosial Politik." Jakarta: Gramedia.

Gusmian, Islah. 2005. "Dialektika Tafsir Al-Qur'an Dan Praktik Politik Rezim Orde Baru." Disertasi UIN Sunan Kalijaga, Yogyakarta.

Gusmian, Islah. 2015. "Tafsir Al-Qur'an Di Indonesia: Sejarah Dan Dinamika." Nun: Jurnal Studi Al-Qur'an Dan Tafsir Di Nusantara 1(1).

Hashim, Shahabuddin. 2007. Teori Personaliti Dari Perspektif Islam, Timur \& Barat. PTS Professional.

Husni, Fithriyawan. 2019. "Tipologi Tafsir Al-Qur'an Di Indonesia Pasca Reformasi: Telaah Pribumisasi Al-Qur'an Karya M. Nur Kholis Setiawan." Mutawatir: Jurnal Keilmuan Tafsir Hadith 9(2):323-51.

Kamsi, Kamsi. 2013. "Citra Gerakan Politik Islam Dalam Lintasan Sejarah Perpolitikan Bangsa Indonesia (Studi Era PRA Kemerdekan Sampai Dengan Era Orde Baru)." Millah: Jurnal Studi Agama 13(1):109-54.

Ma'arif, Muhammad Anas, and Nur Silva Nabila. 2020. "The Contribution Of Kiai Munawwar Adnan Kholil Gresik On Islamic Education." Tribakti: Jurnal Pemikiran Keislaman 31(2):218-36.

MD, Mohammad Mahfud. 2009. "Politik Hukum Di Indonesia [Policy-Oriented in Indonesia]."

Munadzir, Munadzir. 2017. "KONSEP KEPEMIMPINAN MENURUT SYU'BAH ASA." Al-A'raf: Jurnal Pemikiran Islam Dan Filsafat 14(2):253-66.

Rahman, M. T. 2010. "Pluralisme Politik." WAWASAN: Jurnal IImiah Agama Dan Sosial Budaya 34(1):1-13.

Rukin. 2019. Metodologi Penelitian Kualitatif. Jakarta: Yayasan Ahmar Cendekia Indonesia.

Saraswati, Ekarini. 1998. "Rekayasa Bahasa Politik Orde Lama Dan Orde Baru Sebagai Pijakan Berfikir Secara Transparan." Bestari (27):245848.

Shihab, M. Quraish. 2002. "Tafsir Al-Misbah." Jakarta: Lentera Hati 2.

Siregar, Insan Fahmi. 2011. "DINAMIKA DEMOKRASI DI INDONESIA MASA ORDE LAMA: STUDI KASUS ANTARA SUKARNO VERSUS MASYUMI." Paramita: Historical Studies Journal 21(1).

Sudibyo, Agus. 1998. "DE-SOEKARNOISASI DALAM WACANA RESMI ORDE BARU: Kilas-BalikPraktek-Praktek Rekayasa Kebenaran Dan." JSP 2(1).

Sugiyono. 2015. "Metode Penelitian Kombinasi (Mixed Methods)." Bandung: Alfabeta.

Syahid, Bakri. 1979. "Al-Huda: Tafsir Qur'an Basa Jawi." Yogyakarya: Bagus Arafah.

Wahid, Abdul. 2017. "Sosial Politik Dalam Tafsir HAMKA." ARICIS PROCEEDINGS 1.

Wathani, Syamsul. 2016. "Tafsir Al-Qur'an Dan Kekuasaan Politik Di Indonesia (Persfektif Analisis Wacana Dan Dialektika)." Nun 2(1):266120.

Wibisono, M. Yusuf. 2021. "Agama Dan Resolusi Konflik."

Zulaiha, Eni. 2017. "Tafsir Kontemporer: Metodologi, Paradigma Dan Standar Validitasnya." Wawasan: Jurnal IImiah Agama Dan Sosial Budaya 2(1):81-94.

(C) 2021 by the authors. Submitted for possible open access publication under the terms and conditions of the Creative Commons Attribution (CC BY SA) license (http://creativecommons.org/licenses/by-sa/4.0/). 